\title{
実験ワンポイント
}

\section{ダイヤモンドアンビルを用いた 赤外吸収測定の基礎技術}

- A basdic technique for IR measurement with diamond anvils -

\section{青木 勝敏}

Katsutoshi Aoki

Diamond - anvil - cell is a very powerful device for studing pressure-induced phase transition and chemical reaction by spectroscopy such as Raman scattering and IR absorption. Very thin diamond anvils and pressure transmitting mediums used for IR measurement are described.

ダイヤモンドは広い波長領域の電磁波に対して高 い透過率を持つ。この特長を活かして各種の分光測 定がダイヤモンドアンビルを用いて高圧下で行われ ている。分光測定を行う際の実験上のポイントは光 学的にみたダイヤモンドの質である。さらに、その 形状も良質なスペクトルを得る上で考慮すべき重要 なポイントになる。本稿では私たちが赤外吸収実験 に使用しているダイヤモンドアンビルの形状と圧力 媒体について紹介する。

\section{ダイヤモンドの選定}

アンビルとして使われているダイヤモンドはタイ プIAとタイプIIAである。タイプIA は窒素を不 純物として含んでいるため、1100〜 $1300 \mathrm{~cm}^{-1}$ (波 長にして9〜 $7.7 \mu \mathrm{m})$ に強い吸収を持つがタイプ IIAにはこの吸収は見られない(Fig.1)。可視光領 域にはいずれのダイヤモンドも吸収はなく透明であ る。従って、アルゴンやクリプトンなどの可視光レ 一ザを励起光に用いたラマン散乱測定にはタイプ I A を、赤外領域の吸収測定にはタイプIAを使う のが一般的である。

タイプII A品質管理が十分なされており、IIA と指定して購入したアンビル数個の赤外吸収スペ クトルを測定し比較したところ差異は見られなかっ た。

本稿の目的と直接には関係ないがタイプ IAの品 質のチェックについて触れておきたい。ラマン散乱
測定で問題になるのはダイヤモンドからの蛍光であ り、試料からの微弱なラマンピークを観測するため にはダイヤモンドからのバックグラウンドを極力抑 えることが望ましい。蛍光の強さを測定してアンビ ルを選定したいのだが既に完成されたアンビルの中 からユーザが選び出す事は嫌がられ、事実上出来な い。私たちはダイヤモンドの原石の蛍光を測定し、 基準に合格したものを研磨してアンビルとして使用 する事にしている。

原石のラマンスペクトルを $100 \sim 3500 \mathrm{~cm}^{-1}$ の領 域で測定する。励起光は出来るだけ短波長が良く、 クリプトンの青色の $482.5 \mathrm{~nm}$ を使っている。ダイヤ モンドの一次のラマンピークの強度 $\left(I_{\mathrm{D}}\right)$ とある波数 領域の強度の比をとり、その比が小さいものを選ぶ。 当初、ダイヤモンドの一次ピーク $\left(1332 \mathrm{~cm}^{-1}\right)$ と二次 ピーク $\left(2500 \mathrm{~cm}^{-1}\right.$ 付近)の間を比較すべき領域とし ていたが、测定の手間を省くため現在は $500 \mathrm{~cm}^{-1}$

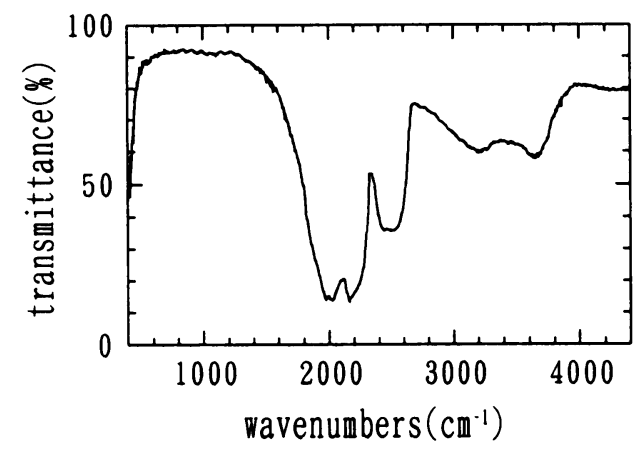

Fig.1. Transmittance of type - IIA diamond. 
と $1000 \mathrm{~cm}^{-1}$ の 2 点を使っている。 $I / I_{\mathrm{D}}$ の值は概ね 1 〜 $2 \times 10^{-3}$ であるが中には一桁以上大きいものも混 在している。実際、<1.5 × $10^{-3}$ の条件をクリアし たのは 26 個の原石の内わずかに 8 個であった。

\section{赤外吸収用アンビルの形状}

タイプ IAのアンビルでは $1100 〜 1300 \mathrm{~cm}^{-1}$ の不 純物吸収は見られないと述べたが、1600〜 2600 $\mathrm{cm}^{-1}$ の広い領域に現れる赤外活性の 2 音子吸収は 避けられない。従って、この領域でも吸収ピークを 観測する必要があるのであ执ばダイヤモンドアンビ ルを薄くするしか手だてはない。Fig.1に示したス ペクトルは厚さ $2 \mathrm{~mm}$ のダイヤモンドの吸収である が、 2000 と $2150 \mathrm{~cm}^{-1}$ 付近の最大吸収領域でも $10 \%$ の光が透過してくることが分かる。すなわち、高さ $1.0 \mathrm{~mm}$ のアンビルを対向させて用いれば赤外の全 波数領域で吸収スペクトルが測定できるわけである。 実際、分子性結晶などでは夕゙イヤモンドの吸収帯之 重なって赤外吸収ピークを持つものも多く、従来の 高圧赤外吸収測定では捨てられていたこの波数領域 の復活は非常に重要である。

このような観点から設計したのが Fig.2に示す小 型アンビルである。いわゆるドルッカータイプであ るが、キュレットは16角形にカットされている。高 さ $1.0 \mathrm{~mm}$ 、ガードル径 $2.0 \mathrm{~mm}$ と超小型である。 タイプIIAのダイヤモンドの価格は IAの 2 3 倍之 高価になるが、図のような小型アンビル(カラット

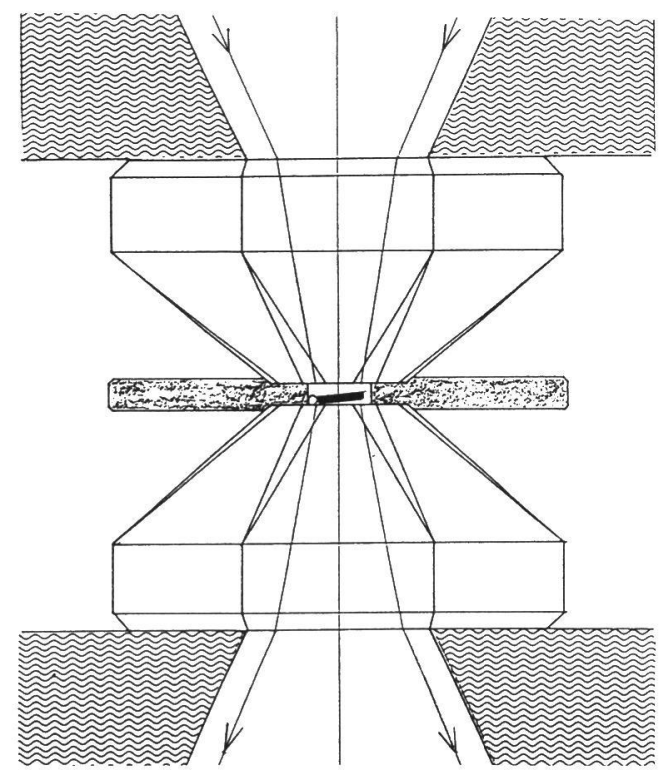

Fig.2 Diamond anvils for IR measurement.
数にして 0.05)の価格は 8〜9万円程度であり、破損 を気にせずに気楽に高圧実験が楽しめる。

次の問題は発生圧力である。ラマン散乱実験やX 線回折実験では同じくドルッカータイプの高さ 2.1 $\mathrm{mm}$ のアンビル (0.2カラット)を標準使用しており、 キュレット径 $0.6 \mathrm{~mm}$ のアンビルでは $30 \mathrm{GPa}$ を安全 使用限界として使用している。高さ $1 \mathrm{~mm}$ のアンビ ルで一体どこまで圧力を上げられるかが興味のある ところであった。現在、キュレット径 $0.6 \mathrm{~mm}$ と 0.5 $\mathrm{mm}$ の小型アンビルを使用しているが、それぞれ $16 \mathrm{GPa}$ と $21 \mathrm{GPa}$ の圧力を発生した実績がある。ま だまだ余力が残っていそうで、破損を覚悟して加圧 す杖さらに圧力は伸びそうである。

\section{高圧赤外吸収測定}

私たちは顕微専用の FT - IR 使ってスペクトル を測定している。顕微専用機は、測定したい領域以 外のマスキング、反射/透過のワンタッチ切替えな ど操作性に優れているが、分解能(例えば $\mathrm{H}$ 社のも のでは標準仕様で $\left.4 \mathrm{~cm}^{-1}\right)$ に不満がある。私たちは 干渉計に改良を加え分解能を $0.5 \mathrm{~cm}^{-1}$ まで高めたも のを使用している。気体などと比べて分子間相互作 用が強い固体では赤外吸収ピークのピーク幅は広く なるため、ピークの圧力シフトなどの測定ではこの 分解能でも十分である。しかし、ピークの形状の微 妙な変化などを測定するためには $0.1 \mathrm{~cm}^{-1}$ 程度の分 解能が欲しいところである。

圧力媒体にはキセノンやクリプトンなどの希ガス を使用している。またヨウ化セシウムなどのアルカ リハライドも試料によっては使用する。これらの物 質は赤外不活性であるため試料の吸収ピークが圧力 媒体の吸収に隠されることはない。ラマン散乱やX 線回折で使われているアルコール混合液は多数の強 い赤外吸収ピークを持つので不適当である。キセノ ンやクリプトンは液体窒素で泠却したダイヤモンド セルの試料部にそれらのガスを吹き付け固化させた 後、セルを閉じてガスケット内に封入する。静水压 性を考慮するとアルゴンがより好ましいが、アルゴ ンの沸点は窒素の沸点と近いため上述の様に固化さ せて封入することは困難である。液体アルゴン中で ダイヤモンドセルを閉じてアルゴンを封じ込む方が むしろ容易であるようにも思える。いずれ、試みる ことにしたい。

〔1993年6月7日受理〕 